\title{
Espaço Urbano e Recursos Hídricos: Uma Análise dos Impactos Ambientais Cau- sados pelo Cemitério Campo Santo José Augusto na Cidade de lbateguara/AL
}

\section{Urban Space and Water Resources: An Analysis of the Environmental Impacts Caused by Campo Santo José Augusto Cemetery in the City of lbateguara / AL}

\author{
Célio Martins da Rocha * \\ Elayne Cristina Pereira dos Santos* \\ Claudionor de Oliveira Silva **
}

\section{Resumo:}

As cidades sofreram um imenso crescimento desordenado, levando às famílias construírem suas residências nas proximidades dos cemitérios. O objetivo do trabalho foi identificar os principais problemas socioambientais causados pelo cemitério de Ibateguara-AL. A metodologia utilizada foi pesquisa bibliográfica, pesquisas de campo, coleta de material, aplicação de questionários. Foi realizada uma análise da Água do Chafariz e da SAMAE. Os resultados se confrontam com o que rege a resolução 335/336/368 e 2003/2006 do CONAMA, de maneira que há grandes possibilidades de degradação do solo e contaminação das águas pelo necrochorume, levando em conta a instalação de um chafariz em frente ao cemitério. A rede de esgoto passa em baixo das catacumbas, sem contar com a grande quantidade de resíduos dentro da necrópole.

Abstract:

The cities have experienced an immense disorderly growth, causing the families to build their residences near the cemeteries. The objective of this study was to identify the main socio-environmental problems caused by the Ibateguara-AL cemetery. The methodology used was bibliographic research, field research, material collection, questionnaire application. An analysis was made of Água do Chafariz. and SAMAE. The results are in line with CONAMA's resolution $335 / 336 / 368$ and $2003 / 2006$, so that there is a great possibility of soil degradation and contamination of water by necrochorume, taking into account the installation of a fountain in front of the cemetery. The sewage network passes beneath the catacombs, not counting the large amount of waste inside the necropolis.

* Estudante de Geografia da Universidade Estadual de Alagoas-UNEAL)

** Doutorando do Curso de Pós-Graduação em Ambiente e Desenvolvimento da Universidade do Vale do Taquari - UNIVATES/RS. Professor da UNEAL
Palavras-chave:

Necrochorume, SAMAE, Necrópoles, Ibateguara.

Key-Words:

Graveyard slurry, SAMAE,

Necropolis, Ibateguara. 


\section{INTRODUÇÃO}

$A$ cidade que queremos morar não pode ser separada dos laços sociais e nem da natureza. A cidade deve ser o lugar desejado, igualitário, saudável, sem o fenômeno de classe. De acordo com Corrêa (1969), a cidade é o espaço da diversificação do consumo, propaganda e distribui $\neg$ ção de bens e serviços do movimento de pessoas e objetos sobre o território. Dessa forma, é preciso estudar a cidade não como um bloco maciço, mas como um conjunto de relações dinâmicas que requerem cada movimento social, novas formas de compreender e apreender as relações que se estabelecem entre o espaço e a sociedade, o meio, a cultura, o lugar com o movimento global, a cidade, o campo e o homem enquanto sujeito. Dessa forma "A humanidade atingiu um estágio tecnológico que permite transformar os cenários naturais de maneira tão rápida e voraz que a natureza não consegue se recuperar" [...] (PESSOA DE MELO E MELO E SOUZA 2015, P.184).

Assim, de acordo com Carneiro (2010, p.87), o planejamento urbano nada mais é do que um processo de idealização, de criação e de desenvolvimento de soluções para os problemas que surgem diariamente nas cidades.

O estudo tem importância para a construção do conhecimento acerca das problemáticas ambientais que nos rodeiam, assim como de algo que está tão perto da sociedade e por não conhecer suas características e malefícios que podem causar a sociedade, acabam passando despercebido em nossos estudos.

A escolha do Cemitério Municipal Campo Santo José Augusto para realização do trabalho foi baseada no seu possível potencial poluidor, fato desconhecido por muitos, pelo mesmo está em uma área de densa ocupação humana e próximo aos dois sistemas de águas da cidade, a SAMAE (Serviço Autônomo Municipal de Água E Esgoto) e a CASAL (Companhia de Saneamento de Alagoas).

As cidades, principalmente nos tempos atuais, desempenham um papel importante na vida da população, mas pelas construções irregulares e pelas ações que o homem faz ao seu entorno são vários os problemas que se encontram e que são prejudiciais para a sua saúde, seu cotidiano e para o ambiente; assim, ocorre na cidade de Ibateguara, fonte de nossa pesquisa. O objetivo do trabalho foi identificar os principais problemas socioambientais causados pelo cemitério de Ibateguara - AL.

\section{O ESPAÇO URBANO E O CEMITÉRIO}

Desde primórdios que o ser humano tem se preocupado com o que fazer com os corpos dos entes queridos. No período neolítico, os corpos eram sepultados em cavernas, logo após, passaram-se a construir sepulturas artificiais. Segundo Lewis Mumford (1998), "a cidade dos mortos antecede a cidade dos vivos", pois foram os mortos os primeiros a fixar em um determinado lugar. Para muitos, a morte é algo inexplicável. Este fato fez com que os egípcios na antiguidade acreditassem na vida após a morte, e para conservar o corpo ao máximo os egípcios fizeram o processo de mumificação.

Os faraós, além de mumificarem os corpos, ainda os colocavam em templos gigantes e em formato de pirâmides. $\mathrm{Na}$ antiguidade, as cidades gregas e romanas eram os mortos os primeiros a recepcionar os visitantes, pois as mesmas eram circundadas de sepulturas e lápides. Muitos dos costumes existentes hoje advém desta época, como colocar flores sobre os túmulos, transcrever nas lápides tumulares.

A partir do século XVII, a forma mais habitual encontrada foi enterrar os mortos. A princípio, as pessoas eram enterradas dentro das igrejas ou no seu entorno. Acreditavase na época que isto lhes traria a salvação divina. Os ricos eram enterrados em locais diferentes. Com o tempo, os corpos começaram a exalar um cheiro forte do qual começou a incomodar as pessoas que frequentavam a igreja, e chegaram a pensar que inalando o cheiro poderiam adquirir a doença pela qual levou a pessoa a óbito.

Esta prática foi proibida no século XX, pois a igreja alegava não serem saudáveis nem higiênicos aos fiéis; os mesmos, por sua vez, irritaram-se e geraram confusão, acreditando que sendo enterrado longe da igreja não havia salvação. Devido a estes costumes, que a memória dos mortos é respeitada e cultuada, até os dias atuais em diferentes formas. Desta forma, conclui-se que:

Os cemitérios são monumentos à memória daqueles que mor-
reram e que os vivos fazem questão de perpetuar. Consequen-
temente, este tipo de construção adquiriu a condição de invio-
labilidade no que tange à pesquisa científica nos seus diferentes
aspectos. Entretanto, sociólogos, antropólogos, folcloristas e
outros têm dado excelentes contribuições para um melhor co-
nhecimento dos hábitos, costumes e práticas funerárias (MA-
TOS, 2001, p. 01).

A partir disso, sugiram os cemitérios. Mas os mesmos não amenizaram os impactos causados ao meio ambiente. Segundo o art. 12, da Resolução CONAMA no 237, de 1997, permite a criação de critérios para agilizar e simplificar os procedimentos de licenciamento ambiental das atividades e empreendimentos similares, visando a melhoria contínua e o aprimoramento da gestão ambiental, resolve: Art. 1'a ; cemitérios horizontais e os cemitérios verticais, doravante de- 
nominados cemitérios, deverão ser submetidos ao processo de licenciamento ambiental, nos termos desta resolução, sem prejuízo de outras normas aplicáveis à espécie.

Segundo Campos (2007), os tipos de cemitérios existentes no Brasil e no mundo com suas vantagens e desvantagens são: Os cemitérios tradicionais ou horizontais: são compostos por alamedas pavimentadas, túmulos semienterrados, mausoléus, capelas com altar, crucifixos e imagens, monumentos funerários revestidos de mármores e granitos, com pouca ou nenhuma arborização. Geralmente os corpos são enterrados diretamente no solo. Vantagem: em função do contato do corpo inumado com o solo, é facilitada a decomposição. Desvantagem: possibilidade de contaminação de águas superficiais e subterrâneas, ocupação de grandes áreas, alto custo, devido à preocupação com ostentação, necessidade de solo adequado para esta finalidade, ambiente acinzentado que afeta a estética urbana e pode gerar impactos psicológicos em pessoas sensíveis, possível proliferação de insetos como os mosquitos transmissores de dengue e febre amarela, e artrópode, como escorpiões encontrados em locais escuros, úmidos e abrigados.

\subsection{Impactos Ambientais}

Recentemente a sociedade está preocupada com a escassez dos recursos naturais, valorizando a proteção desses recursos, dando nova dimensão à questão ambiental. Tendo em vista que a relação homem, natureza deve se dá de forma respeitosa que garante o atendimento das necessidades do presente sem comprometer a capacidade das gerações futuras atenderem também às suas necessidades. Assim, “a prevenção é um importante instrumento para mitigação do risco" [...] (PESSOA DE MELO; MELO E SOUZA; SANCHES ROSS, 2016. p. 103). Nesse contexto, a legislação brasileira, considera-se impacto ambiental:

\section{qualquer alteração das propriedades físicas, químicas e biológi- cas do meio ambiente causada por qualquer forma de matéria ou energia resultante das atividades humanas que direta ou in- diretamente, afetam: I - a saúde, a segurança e o bem-estar da população; II - as atividades sociais e econômicas; III - a biota; IV - as condições estéticas e sanitárias do meio ambiente; e V - a qualidade dos recursos ambientais (Resolução CONAMA 001, de 23.01.1986)}

A definição ambiente como relações dos homens com a natureza para preservação dos recursos naturais em processos de desenvolvimento sustentável. Com a ação antrópica presente no meio ambiente, cada vez mais alterando o mesmo, aumentaram os debates em âmbito mundial a respeito desta problemática, como a conferência das nações unidas sobre o meio ambiente humano realizada em Estocolmo,
1972, Eco 92, Rio +10, dentre outras.

A respeito da legislação específica, para implantação de cemitérios constatamos que na esfera federal não havia legislação ou norma técnica regulamentando a implantação e a operação de cemitérios em termos ambientais e sanitários.

O Conselho Nacional de Meio Ambiente (CONAMA) promulgou a Resolução no 335 , que dispõem sobre o licenciamento ambiental de cemitérios. Esta lei foi reformulada em 28 de março de 2006, com a Resolução do CONAMA $\mathrm{n}^{\circ}$ 368. Porém, pode-se perceber que existem falhas nestas leis (FOFONKA; KUNT, 2006 apud KEMERICH et al., 2014, p. 3783).

Os cemitérios instalados antes da vigência da Resolução n 335 devem se adaptar às suas regras, sendo que os órgãos estaduais e municipais de meio ambiente deverão estabelecer, até dezembro do corrente ano, os critérios para a adequação, conforme menciona o artigo 11, cuja redação foi dada pela Resolução CONAMA no 402, de 17 de novembro de 2008 (WEBER, 2010 apud KEMERICH et al., 2014, p. 3783).

O subsolo da área pretendida para o cemitério deverá ser constituído por materiais com coeficientes de permeabilidade entre 10,5 e 10,7 cm/s, na faixa compreendida entre o fundo das sepulturas e o nível do lençol freático, medido no fim da estação das cheias. Para permeabilidades maiores, é necessário que o nível inferior dos jazigos esteja dez metros acima do nível do lençol freático (BRASIL, 2003. Art. 5, Paragrafo $1^{\circ}$, inciso III).

$\mathrm{O}$ perímetro e o interior do cemitério deverão ser providos de um sistema de drenagem adequado e eficiente, destinado a captar, encaminhar e dispor, de maneira segura, o escoamento das águas pluviais e evitar erosões, alagamentos e movimentos de terra (BRASIL, 2003. Resolução 335. Art.5, Parágrafo $1^{\circ}$, inciso II).

A Resolução proíbe a instalação de cemitérios em Áreas de Preservação Permanente ou em outras áreas que exijam desmatamento de Mata Atlântica primária ou secundária, em estágio médio ou avançado de regeneração, em terrenos predominantemente cáusticos, que apresentam cavernas, sumidouros ou rios subterrâneos, em áreas de manancial para abastecimento humano, bem como naquelas que tenham seu uso restrito pela legislação vigentes ressalvadas as exceções legais previstas (WEBER, 2010 apud KEMERICH et al., 2014, p. 3783).

Nos cemitérios construídos mais recentemente, o risco de contaminação é bem menor. Desde 2003, a legislação estipula, entre outros itens, que não podem ocupar áreas de preservação ambiental, nem terrenos sob os quais o lençol freático passa a menos de $5 \mathrm{~m}$ de profundidade, além de dispor sobre normas para construção dos jazigos a fim de evi- 
tar a infiltração do necrochorume no solo (CHRISTANTE, 2011 apud KEMERICH et al., 2014, p. 3783).

Para amenizar os impactos causados pelos cemitérios, as normas condicionam este tipo de empreendimento à realização do EIA/RIMA. Para que este relatório seja fornecido, é feito o estudo prévio de viabilidade, identificando as condições do local, tipo de solo, localização e profundidade do lençol freático. Além disso, a obra deve ser feita verificando outros fatores de importância que o terreno em questão necessite, para a implantação de um cemitério (WEBER, 2010 apud KEMERICH et al., 2014, p. 3783).

Até o ano e 2003, mais precisamente maio de 2003, o Brasil não tinha qualquer dispositivo legal federal sobre cemitérios. No Conselho Nacional do Meio Ambiente (Conama), foi promulgada a Resolução no 335 que dispõe sobre o licenciamento ambiental de cemitérios ambientais e verticais.

A resolução estabeleceu critérios mínimos para a implantação de novos cemitérios. Tais medidas foram tomadas a fim de garantir a decomposição normal dos corpos e proteger os lençóis freáticos da infiltração do necrochorume. A resolução ainda deu prazo de 180 dias para que os cemitérios já existentes se adequassem às novas normas. Devido ao imenso risco que os cemitérios causam ao meio ambiente, para tanto é necessário uma licença ambiental para que o mesmo seja implantado e para que haja sua manutenção. Assim:

A resolução CONAMA No 335/2003, estabelece critério mínimos que devem ser integralmente estabelecido para o fornecimento da licença ambiental para o funcionamento dos cemitérios e prever que os órgãos estaduais e municipais de meio ambientes devem estabelecer até dezembro de 2010 critérios para adequação dos cemitérios existentes desde 2003. Portanto, desde 2003 todos os cemitérios devem se adequar a resolução CONAMA 335/2003, O não comprimento da resolução acarretará responsabilidades civis, penais e administrativas, bem como multas diárias e outras obrigações (arts. 14 e 15 da resolução do CONAMA 335/2003) apud (NOGUEIRA, JÚNIOR, COIMBRA, 2013, p.337).

Ainda de acordo com os autores supracitados acima:

A resolução 335/2003 denomina os cemitérios horizontais e os cemitérios verticais, e explica que estes deverão ser submetidos ao processo de licenciamento ambiental, conforme determinado pela própria resolução, sem prejuízo de outras normas aplicáveis a espécie, veda a instalação de cemitérios em áreas de preservação permanente - APP, ou em outras que exijam desmatamento da mata atlântica primaria ou secundária, em estágio médio ou avançado de regeneração em terrenos predominantemente cársticos, que apresentam cavernas, sumidouro ou rios subterrâneos, bem como naquelas que tenham seu uso restrito pela legislação vigente, exceto quando a lei expressamente prever. (NOGUEIRA; JÚNIOR; COIMBRA, 2013, p. 338).
Todo esse cuidado é necessário desde que os sepultamentos dos cadáveres são uma fonte recorrente para a poluição do meio ambiente. Para que haja a minimização do problema é necessário que a implantação dos cemitérios novos sejam planejados conforme normas de arquitetura e engenharia para sua construção longe de aglomerações humanas ou, para melhor dizer, longe das produções urbanas.

É importante salientar ainda que é necessário que exista um planejamento onde a drenagem das águas das chuvas possa correr sem causar inundação nos túmulos, estes são inundados provocando um retardo no processo de decomposição dos corpos, impactando o ambiente e provocando um imenso odor, assim:

Outro aspecto importante a ser observado na resolução é que os corpos sepultados poderão estar envoltos por mantas ou urnas constituídas de materiais biodegradáveis, não sendo recomendado o emprego de plásticos, tintas vernizes, metais pesados ou qualquer material nocivo do meio ambiente. E, proíbe o emprego de material impermeável que impeça a troca gasosa do corpo sepultado com o meio que o envolve, exceto nos casos específicos previstos na legislação. (NOGUEIRA; JÚNIOR; COIMBRA. 2010 p. 338).

De fato a degradação socioambiental causada por cemitérios perpassa por um conjunto de fatos políticos que não recebem o devido planejamento por parte do órgão responsável, pela implantação e manutenção dos jazigos. A falta de fiscalização por parte do órgão de licenciamento ambiental também deixa a desejar, e quem sofre com isso é o meio ambiente e a população que é leiga quanto ao risco à saúde.

\subsection{Degradação Ambiental}

A degradação ambiental é a redução dos potenciais dos recursos renováveis, provocados por diversos agentes e processos. Esses processos diminuir a capacidade do ambiente sustentar as espécies vivas. Os mesmos podem ocorrer por ações antrópicas. Assim, [...] "nesse novo marketing apela-se para preservação, conservação, sustentabilidade" (PESSOA DE MELO E MELO E SOUZA 2015, p. 10).

O solo é um elemento importante no desenvolvimento das sociedades. Neste está a história de um povo, a cultura, a economia e a política. Quando pensamos em solo, em nossa mente diretamente relaciona ao chão que pisamos; este mesmo solo que é capaz de produzir os alimentos que consumimos. Neste mesmo há nutrientes que são necessários para o processo de plantação e desenvolvimento das lavouras; o mesmo também varia de região para região de acordo com o clima. Segundo a Associação Brasileira de Normas Técnicas, ABNT, definem solo como "o resultado 
das interações presentes entre o clima, o material de origem, os organismos vivos e o homem, afirmando ser a camada mais superior da crosta terrestre" (CARNEIRO, 2010, p. 18).

O solo pode ter diversos significados a depender do olhar de cada indivíduo. O mesmo também passa por diversos fatores que impactam diretamente na vida do agricultor, como a falta de chuvas ou até mesmo o excesso delas que acabam por agredir o solo, desgastando-o ou provocando a lixiviação.

O solo ainda é fonte de despejos dos resíduos produzidos pelo homem e pelos seres vivos que perpetuam na terra. É considerado para o homem do campo como Sagrado, pois é o lugar de sua moradia, é fonte de sua subsistência. Nele estão a vida, a história e a cultura de um povo. Para os agentes modeladores do espaço, como os engenheiros, o solo é apenas um material que está ali para ser utilizado para fins lucrativos e suas escavações na construção de edifícios. Já para os pedólogos;

Os profissionais ligados diretamente ao solo, os Pedólogos, tratam o solo como um corpo natural, com constituintes minerais e orgânicos, diferenciando-os por horizontes, profundidades, características físicas, químicas e biológicas, por suas propriedades, e ainda pela biota encontrada abaixo da terra. Há diferenças ainda por suas cores, texturas, variando seus horizontes de poucos centímetros a vários metros de espessura, onde todas essas características juntas formam o que se chama de perfil de solo. (CARNEIRO, 2010, p. 18).

Ocorre também pela introdução de produtos poluentes em estado sólido, líquido e gasoso, comprometendo a saúde do homem e de outros seres vivos, sejam estes animais ou vegetais.

A poluição do solo provoca graves problemas ao ambiente, além de prejudicar a saúde do homem. O mesmo também altera a cadeia alimentar, provocando um desequilíbrio no ecossistema, como a perda da cobertura vegetal, contaminação dos lençóis freáticos e falta de fertilidade dos solos.

\subsection{A Poluição das Águas}

A água, um bem essencial para a sobrevivência do ser humano, um recurso renovável de grande abundância na superfície terrestre, pode ser encontrada em vários estados. A porção líquida e doce é a mais consumida pela população, podendo ser encontrada tanto na superfície terrestre quanto subterrânea. Mas, para o consumo humano, a água tem que ser potável e de boa qualidade, para que não haja risco à saúde.

Devido a sua abundância por muito tempo pensava-se que este recurso hídrico nunca seria escasso, atualmente existem vários conflitos entorno dele e sua existência está chegando ao fim. Existem vários órgãos responsáveis pela preservação da água como: CNRH - Conselho Nacional de Recursos Hídricos, ANA- Agência Nacional de Águas, etc.

Para implantação de cemitérios, existem algumas normas que devem ser respeitadas. $\mathrm{O}$ Art. $1^{\circ}$ Resolução $\mathrm{n}^{\circ}$ 335, de 3 de abril de 2003, do CONAMA passa a vigorar com a seguinte redação:

$\int 10$ É proibida a instalação de cemitérios em Áreas de Preservação Permanente ou em outras que exijam desmatamento de Mata Atlântica primária ou secundária, em estágio médio ou avançado de regeneração, em terrenos predominantemente cársticos, que apresentam cavernas, sumidouros ou rios subterrâneos, bem como naquelas que tenham seu uso restrito pela legislação vigente, ressalvadas as exceções legais previstas.

O CONAMA também especifica que o nível inferior das sepulturas esteja a uma distância de pelo menos um metro e meio do nível do lençol freático.

Antes da instalação dos cemitérios é necessário analisar a área, o solo, ter licenciamento ambiental, levar em consideração os possíveis riscos ao meio ambiente e a população.

A preocupação com a proximidade dos cemitérios das cidades vem desde o século XVIII, mas a preocupação com a poluição causada pelos cemitérios é bem mais recente. Apenas em 1998, a OMS (Organização Mundial de Saúde) publicou um relatório afirmando que os cemitérios seriam uma fonte potencial de poluição, podendo causar impactos ambientais no solo e lençóis freáticos em razão da liberação de substâncias orgânicas e inorgânicas e microrganismos patogênicos. O CONAMA (Conselho Nacional de Meio Ambiente), por meio das resoluções de número 335/2003 e 368/2006, estabeleceu critérios para a implantação de cemitérios, visando proteger os lençóis freáticos da infiltração do necrochorume, e impôs um prazo para que cemitérios já implantados se adequassem às novas regras.

No entanto, estas medidas são pouco consideradas, haja vista que em algumas cidades de áreas bastante pequena a população por falta de local e estrutura adequada, aglomera-se próximo a áreas já então inicializadas pelos órgãos responsáveis, principalmente a população pobre que sofre deveras com as questões de saneamento e acessibilidade dos bens que devem ser ofertados pela rede urbana para uma melhor condição de vida, bem estar e dignidade humana; direitos que não devem ser negados a quaisquer cidadãos. Com base nesta teoria, nos propusemos a realizar uma análise na água do chafariz, localizado em frente ao Cemitério Campo Santo José Augusto e também na SAMAE (Serviço Autônomo Municipal de Água e Esgoto), como mostra a tabela a seguir.

\section{METODOLOGIA}

Segundo o IBGE censo 2010, o município de Ibate- 
guara teve origem no antigo engenho Roçadinho de propriedade de Claudino Costa Agra. Foram lançadas; aí; as bases da povoação que se estenderia e que mais tarde viria a ser o povoado Piquete, que é o primeiro núcleo populacional do atual município. $\mathrm{O}$ nome the foi dado em virtude de um piquete formado pelo Caudilho Vicente de Paula na sua luta contra Claudino da Costa Agra. Em 1959, seu nome foi mudado para Horizonte, permanecendo este nome por pouco tempo. D. Ranulfo de Farias, então Arcebispo de Maceió, sugeriu o topônimo de Ibateguara, nome de origem indígena que significa "lugar alto".

O município de Ibateguara está localizado na microrregião Serrana dos Quilombos na Mata Alagoana com uma altitude de 520 metros acima do nível do mar. Apresenta um clima temperado, com uma temperatura máxima de $28^{\circ} \mathrm{C}$ e mínima de $18^{\circ} \mathrm{C}$, considerando as várias estações do ano. $\mathrm{O}$ município possui uma área total de 254,5 $\mathrm{km}^{2}$, com 15.149 habitantes, com uma densidade demográfica de 59, 35 hab./ $\mathrm{km}^{2}$, foi criada em 1957 , sua latitude é de $08^{\circ} 58^{\prime} 21^{\prime \prime}$ e longitude de $35^{\circ} 56^{\prime} 22^{\prime \prime}$, seus limites geográficos colônia Leopoldina, Quipapá-PE, são José da laje e união dos palmares. Piquete, nome dado a uma vala feita para impedir a passagem dos Cabanos, que tinham a intenção de invadir o Engenho Roçadinho.

O Engenho Roçadinho pertencia à famillia "Costa Agra", desta familia Claudino foi o primeiro prefeito de São José da Laje, e José foi Deputado Provincial das Alagoas (1844). No local desta vala, os Cabanos (Revolução feita pela permanência de D. Pedro I no Brasil) foram obrigados a deixar a região sem realizar a citada invasão e saque ao Engenho. Junto à vala foi levantado um nicho e colocado uma imagem de São Sebastião, com a finalidade de o santo livrar o povo da guerra, fome e peste (doenças). Com o decorrer do tempo, formou-se uma aldeia que se tornou povoado e finalmente distrito do município de São José da Laje (figura 01).

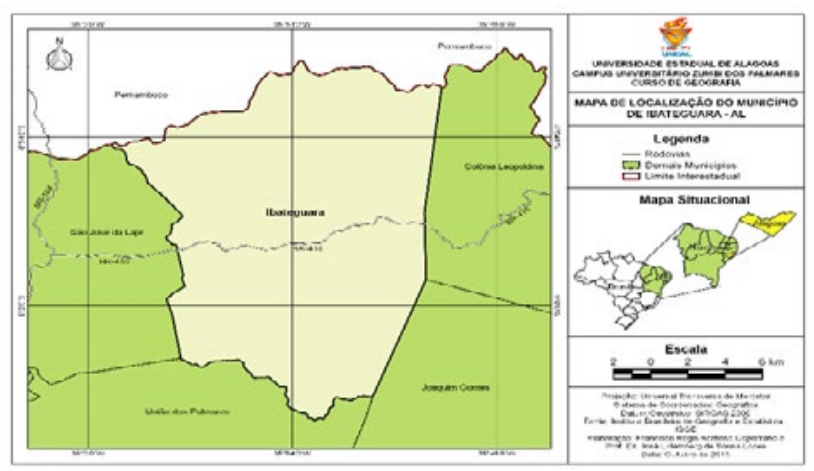

Figura 01- Mapa da Cidade de Ibateguara.

Fonte: Prof. Dr. José Lidemberg de Sousa Lopes - UNEAL Campus V - Zumbi dos Palmares
Sua bacia hidrográfica é integrada pelo rio Jacuípe e pelos riachos Horizonte, Jiboia, Sumidouro, Taquara (limite com Colônia Leopoldina e Pernambuco), Camaragibe (limite com União dos Palmares). Como acidentes geográficos destaques para as serras Vento, com 580 metros de altura e Canastra, com 630 metros.

Segundo dados (Enciclopédia Municípios De Alagoas, 2010, p. 413) Ibateguara é uma localidade com forte influência da pecuária na zona rural, de gado mestiço de corte, búfalos e animais de médio porte como ovinos e caprinos. $\mathrm{Na}$ agricultura, a cultura mais forte ainda é a canavieira devido a sua vizinhança com municípios que possuem usinas de açúcar como são José da laje (serra grande) e colônia Leopoldina (Taquara e destilaria porto alegre). Na lavoura tradicional tem o cultivo de banana, laranja, manga, abacaxi, batata, feijão, mandioca e milho. A cidade é pequena, sem comércio expressivo, com vínculos forte com São José da Laje e principalmente União dos Palmares, onde se concentra a maior demanda de comércio e serviços. Além da usina Serra Grande e da agricultura o comércio local e a administração pública de certa forma geram empregos e rendas para população.

\subsection{Tipos de Pesquisa}

O trabalho em si constitui-se de alguns pontos norteadores dos tipos de pesquisa que decerto tornaram-se indispensáveis para a construção da nossa base teórica e para a construção e ampliação do conhecimento do mesmo, tendo como fontes norteadoras a pesquisa exploratória que objetiva a análise $\mathrm{da}(\mathrm{s})$ hipótese(s) visando à construção empírica do problema no qual viabiliza a busca por respostas cabíveis a situação atual.

Houve a aplicação de questionário in loco para conhecer a situação atual. A utilização da pesquisa proporciona o uso de catalogação depara melhor apresentação dos resultados, bem como a observação do participante. Isto pressupõe o estudo do comportamento humano das condições existenciais de sua vivência, dos reais problemas existenciais nas suas manifestações perante um problema.

\footnotetext{
Quando se fala de pesquisa quantitativa ou qualitativa, e mesmo quando se fala em metodologia quantitativa ou qualitativa, apesar da liberdade de linguagem consagrada pelo uso acadêmico, não se está referindo a uma modalidade de metodologia em particular. [...] cabe referir-se a conjuntos de metodologias, envolvendo, eventualmente, diversas referências epistemológicas. (SEVERINO 2007, p.119).
}

O trabalho consiste ainda em levantamentos bibliográficos a partir de livros, artigos que tratam do referido tema e outros materiais de websites, pesquisa documentais e, principalmente, a pesquisa de campo, esta que certamente permi- 
tiu o alcance dos objetivos.

Tal leitura para o embasamento teórico do trabalho em questão foi realizada por meio de artigos, livros, revistas e TCC, por meio de autores que trata do assunto.

\subsection{Pesquisa de Campo}

A pesquisa de campo tem por objetivo aprofundar o estudo e conhecer a realidade do local de estudo, pois sua função é sanar as curiosidades, os problemas e buscar alternativas para melhor compreensão do tema.

O trabalho em questão constitui-se de questionário com um conjunto de questões desenvolvidas e articuladas, que visam o levantamento de informações descritas pelos anseios do pesquisador, buscando conhecer os sujeitos pesquisados e a opinião dos mesmos acerca do tema trabalhado nestes escritos.

\subsection{Questionários}

O questionário foi realizado através da aplicação porta a porta, nas ruas Miguel Alves e travessa Henrique jatobá, entre os dias 17 e 18 de março de 2016. O mesmo foi elaborado com base nos objetivos deste trabalho, contendo dez perguntas sobre as questões socioambientais de convivência próximo ao cemitério. $\mathrm{O}$ questionário aplicado aos moradores das proximidades do cemitério foi composto por perguntas de caráter de identificação e de ordem socioambiental. Foram visitadas 20 casas, com pessoas de ambos os sexos e idades variadas entre 23 a 68 anos, residentes naquela localidade entre 2 meses a 48 anos.

\subsection{Entrevistas}

As entrevistas foram realizadas no mesmo período e local da aplicação dos questionários. A pesquisa entrevistou também os coveiros, com o objetivo de saber sobre a utilização de equipamentos de proteção individual-EPI. Para a avaliação e a interpretação dos dados, utilizou-se a análise de conteúdos registrados em caderno de campo. Os entrevistados foram de ambos os sexos, com idade entre 26 a 47 anos. Usou-se o programa Microsoft Office Excel para tabulação e construção dos gráficos.

\subsection{Análise da água}

Foram coletadas no dia 06/04/2016, as 8:10h, 2 amostras de água, no Chafariz localizado em frente ao Cemitério e SAMAE, uma casa abastecida por esse sistema, na Ci- dade de Ibateguara. As amostras foram coletadas em fracos plásticos de estéreis de $200 \mathrm{ml}$, contendo $0,2 \mathrm{ml}$ de solução a $10 \%$ de tiossulfato de sódio para neutralizar a ação do cloro residual, mantidas a 4 o $\mathrm{C}$ e analisadas dentro de 24 horas. As análises foram realizadas no Laboratório de Controle da Qualidade da Água-LCQA, Serviço Autônomo De Água E Esgoto-SAAE, localizado no condomínio sueca.

\section{RESULTADOS E DISCUSSÃO}

O primeiro cemitério de Ibateguara estava localizado na rua Ramiro pereira onde atualmente existe casas no local. Devido ao crescimento da população e consequentemente a expansão da cidade, foi construído um novo cemitério em uma parte mais alta da cidade que, na época, era um sítio e não havia residências. "Segundo dona Isabel de 68 anos, residente nesta localidade, próxima ao cemitério, há 48 anos, o mesmo já existia antes dela residir no local; não havia muitas casas e o muro era de arame, depois foi construído o muro de tijolos."

No entanto, sua estrutura apresenta alguns danos, como: Túmulos com rachaduras que permitem infiltração em especial das águas de chuva; problemas provocados pela compactação do solo; além da negligência de proprietários de jazigos nos cemitérios também favorecem de maneira específica a contaminação do lençol freático com impactos ambientais capazes de afetar a saúde pública. O muro do cemitério foi derrubado para a ampliação do mesmo, fato que deixou muitas residências praticamente dentro das necrópoles. Devido ao avanço populacional desta área, hoje se encontra cercada por residências ocupadas por pessoas com menor poder aquisitivo, pois há uma grande desvalorização do solo urbano neste local (figura 2).



Figura 2 - cemitério de Ibateguara

Fonte: Arquivo pessoal dos autores LATITUDE: $8^{\circ} 58^{\prime} 32,77^{\prime \prime} \mathrm{S}-$ LONGITUDE: $35^{\circ} 55^{\prime} 53,1$ ' W, 2016 
O cemitério campo santo José Augusto na figura 02, atende a população de Ibateguara, tanto da área urbana quanto rural. Não existe nenhuma lei orgânica para seu planejamento sua implantação e manutenção. O mesmo não atende as normas do CONAMA, nem a lei estadual para este tipo de empreendimento. No município não existe nenhum registro de quando o cemitério foi instalado. O governo municipal de Ibateguara se absteve de qualquer responsabilidade administrativa com o cemitério e, segundo eles, nenhum órgão municipal é responsável, nem a secretaria do meio ambiente, infraestrutura e vigilância sanitária fiscaliza ou toma medidas para amenizar os impactos gerados pelo cemitério.

\subsection{Impactos causados pelo cemitério de Ibateguara}

De acordo com Barros (2008), no momento de escolher o local da construção de um cemitério, deve haver critérios, observando as características do meio físico (relevo e hidrologia), e atributos do solo (profundidade efetiva, textura, densidade aparente, teor de matéria orgânica, mineralogia da fração de argila, entre outros).

O cemitério de Ibateguara é do tipo horizontal, um dos que mais causam impactos ambientais, pois no mesmo os corpos são enterrados diretamente no solo, podendo causar risco de contaminação hídrica e pedológica (figura 3)

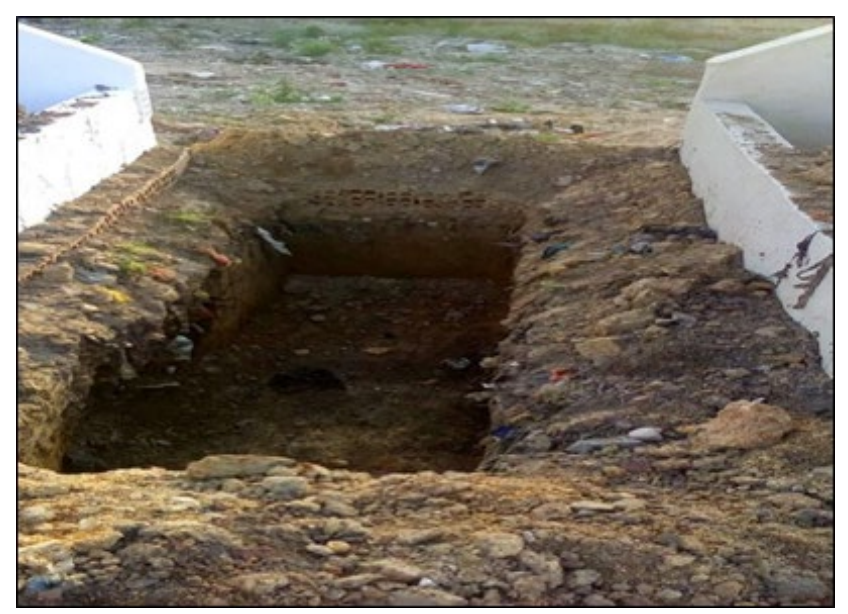

Figura 3- covas de inumação

Fonte: Arquivo pessoal dos autores LATITUDE: $8^{\circ}$ 58' 33, 13" S LONGITUDE: 35 55' 50, 92” W, 2016

Todavia, a tumulação consiste na construção de caixas em alvenaria ou concreto onde são colocados os caixões, podendo conter uma metragem de $1,70 \mathrm{~m}$ de frente, por $2,80 \mathrm{~m}$ de frente a fundo, figura 4. Esse tipo de cova, quando colocada de forma adequada, evita o contato do necrochorume com o solo por meio de sistema de drenagem. O cemitério em questão há apenas a construção de caixas em alvenaria ou concreto, não contando com o sistema de drenagem, o mesmo causa o mesmo risco de contaminação das covas inumação, pois pode ocasionar o escoamento do necrochorume e contaminar o meio ambiente (figura 4).

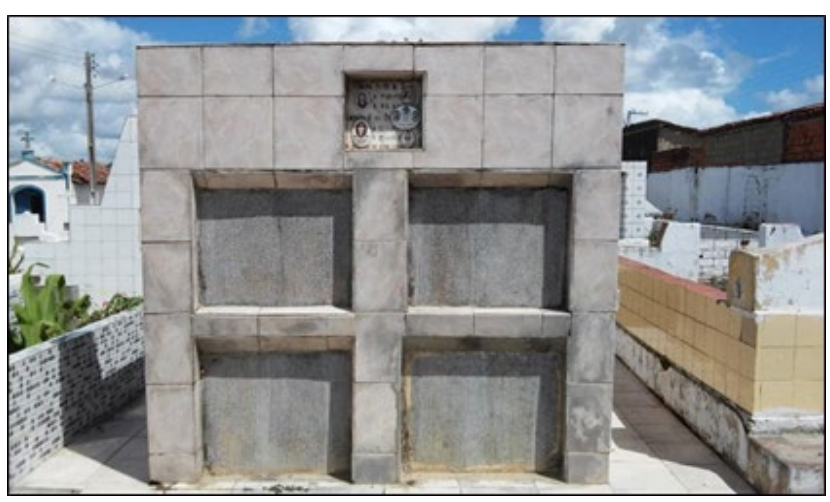

Figura 4-Covas de Tumulação

Fonte: Arquivo pessoal dos autores LATITUDE: $8^{\circ}$ 58' 33, 39" S LONGITUDE: $35^{\circ} 55$ ' 52, 78” W, 2016

A pesquisa revela que o cemitério não atende à legislação, e não adota os critérios e condições técnicas de implantação e manutenção do memo. E durante a elaboração do trabalho não foi cedida nenhuma documentação comprobatória que autorize seu licenciamento.

Por conta dos possíveis problemas sanitários e ambientais que os fenômenos transformativos decorrentes da decomposição dos corpos e a consequente geração do necrochorume, para a implantação e operação de cemitérios é necessário tomar cuidados técnicos e científicos, base em legislação [...] a fim de evitar possíveis riscos e contaminações em aquíferos freáticos. (CAMPOS, 2007, p. 43).

Uma alternativa para amenizar o impacto seria poços de monitoramento contínuo das águas e do solo, pois o necrochorume seria escoado por uma tubulação, evitando contato com o meio ambiente e, consequentemente, não haveria riscos de contaminação. Pôde se constatar durante a pesquisa, a existência de um sistema de água e esgoto dentro do cemitério; o mesmo faz parte das residências vizinhas ao redor do cemitério (figura 5).

O sistema da rede de esgoto encontra-se estourado, causando infiltração nas covas, e algumas sepulturas estão cedendo, e os caixões estão à mostra, aumentando ainda mais o risco de contaminação das aguas subterrâneas e superficiais. Além disso, o processo de decomposição dos cadáveres se torna lento em contado com líquido, aumentando o período do necrochorme escoando no solo e o mal cheiro no local (figura 6).

\subsection{Análise da Água do Chafariz e da SAMAE da cida- de de Ibateguara}


Se fez necessário a análise da água do chafariz que fica localizado no muro da frente do Cemitério Campo Santo José Augusto e também da SAMAE (Serviço Autônomo Municipal de Água e Esgoto), localizada próximo ao local de pesquisa. É de extrema importância saber se o fato da encanação que abastece boa parte da cidade dividir solo com o Cemitério Campo Santo José Augusto está ou não contaminada. Para isso realizamos a análise abaixo (quadro 1).

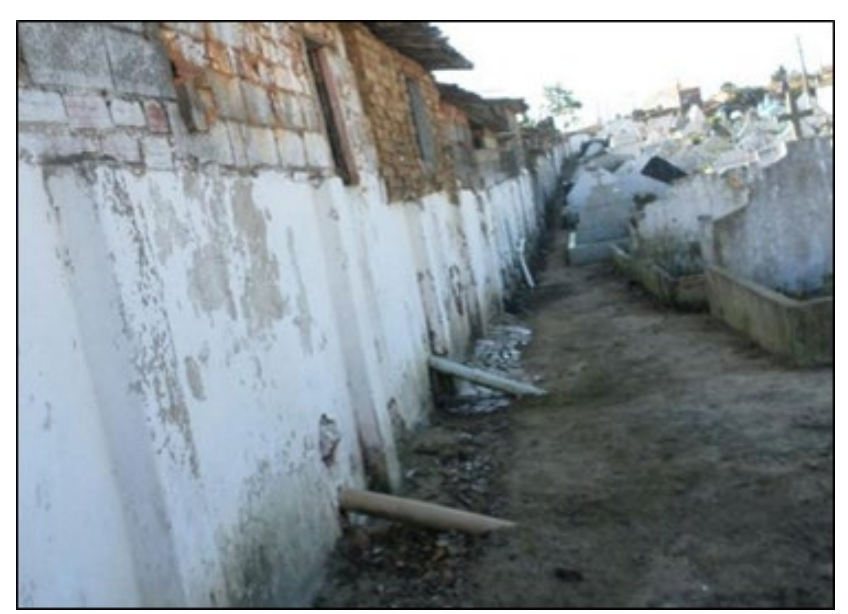

Figura 5 - Encanação do Sistema de Esgoto

Fonte: Arquivo pessoal dos autores LATITUDE: $8^{\circ} 58^{\prime} 36,18$ " S LONGITUDE: $35^{\circ} 55$ '52, 26” W, 2016

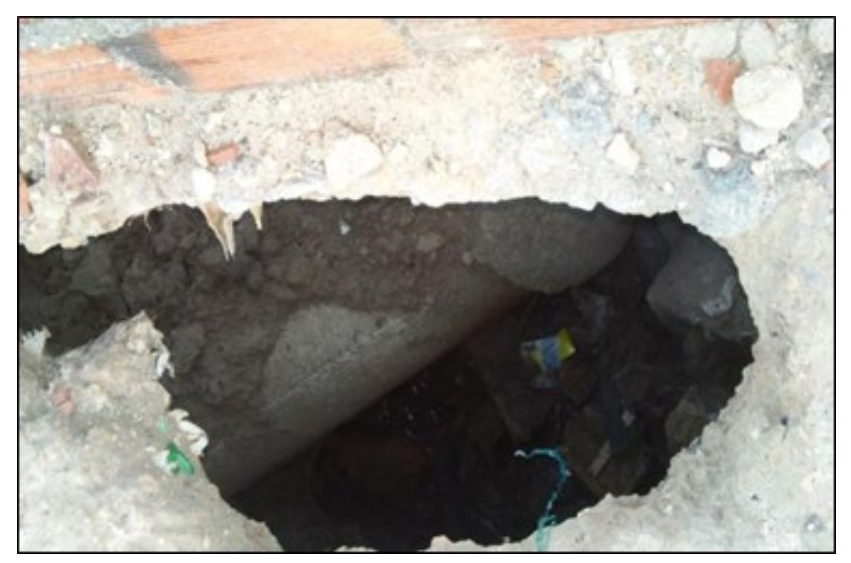

Figura 6 - Rede de Esgoto Estourada

Fonte: Arquivo pessoal dos autores. LATITUDE: 80 58' 34, 34" S LONGITUDE: 35 55' 50, 77” W, 2016

A análise da Água do Chafariz e da SAMAE da cidade de Ibateguara, mostra que não há a presença de bactérias nas águas do chafariz nem tão pouco da SAMAE, porém muito nos assusta a questão da encanação está no solo abaixo do Cemitério Campo Santo José Augusto, levando em conta os acasos do dia a dia. Um possível vazamento nesta encanação pode comprometer toda tubulação ou com a contaminação pelo necrochorume ou pelo chorume dos resíduos sólidos, já que o local de pesquisa serve com depósito de lixo para os moradores daquela região, sem contar com uma terceira possibilidade de contaminação da água que é a rede de esgoto estourada no subsolo que está à mostra e também esgoto a céu aberto que aumenta ainda mais essa probabilidade de contaminação. Observou-se na pesquisa que, a cor da água não atende os parâmetros estabelecidos pelo CONAMA, mesmo assim, grande parte da população já consumiu e outra ainda consome dessa água.

No local, há encanação de água ligada ao sistema de abastecimento das residências vizinhas. Observa-se canos danificados, restos de alimentos, podendo atrair vetores de doenças, como: rato, baratas, caramujo, gerando um grande risco desta água está contaminada (figuras 7 e 8).

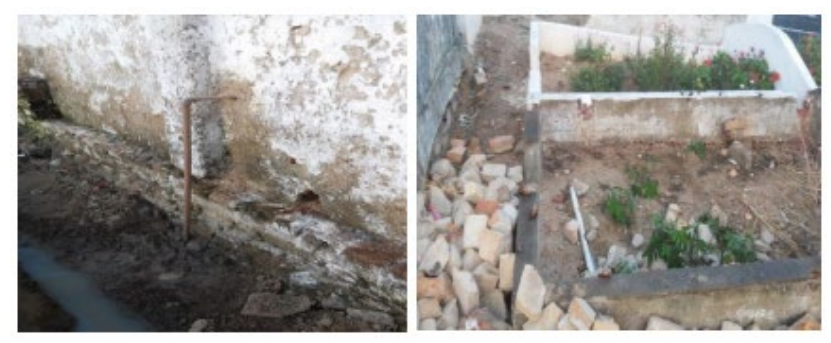

Figura 7 - forma de encanação de água e Figura 8 - caramujos encontrados no cemitério.

Fonte: Arquivo pessoal dos autores LATITUDE: 80 58' 33, 69" S LONGITUDE: $35^{\circ} 55^{\prime} 52,99^{\prime}$ W, figura 7,

LATITUDE: $8^{\circ} 58^{\prime} 32,47$ ' S - LONGITUDE: 35 55' 51, 69” W, Figura 8, 2016

A população do entorno do cemitério é abastecida por dois sistemas de água: o da prefeitura, SAMAE (Sistema autônomo Municipal de água e esgoto) e da CASAL. As casas, cujo o abastecimento é fornecido pelo SAMAE, sofrem com constante falta de água, pois há um desligamento por parte da empresa que alega o não pagamento da taxa comprada pela mesma de alguns usuários. Os (mesmos têm que recorrer a um chafariz que está localizado na frente do cemitério Figura 9).

Ao consumir a água, os moradores podem estar se contaminando com microrganismos que proliferam durante o processo de decomposição dos corpos. Assim, é necessário adotar medidas de controle técnico, como a análise das águas que estão nos poços domésticos e a construção de poços de monitoramento e amostragem de aquífero freático, conforme recomenda a NBR 13.895/1997. (LEITE, 2009, p.34).

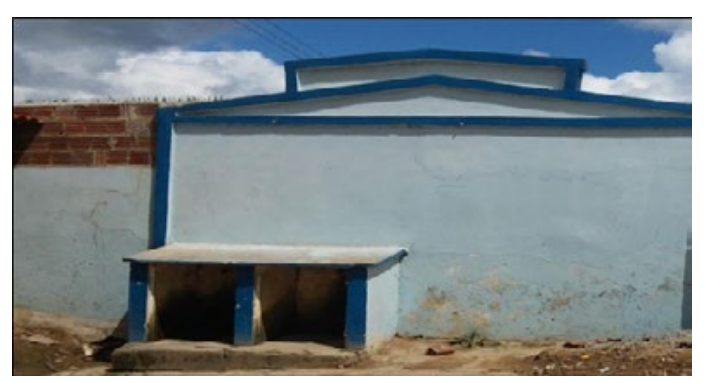

Figura 9-Chafariz localizado na entrada do cemitério

Fonte: Arquivo pessoal dos autores LATITUDE: 8 58' 32, 82" S LONGITUDE: 35 55’ 52, 77” W, 2016 
Quadro 1 - Análise da Água do Chafariz e da SAMAE da cidade de Ibateguara - AL

\begin{tabular}{|c|c|c|c|c|c|c|c|c|}
\hline \multirow{2}{*}{$N^{p}$} & \multirow{2}{*}{\multicolumn{2}{|c|}{ Local do Ponto de coleta }} & \multicolumn{2}{|c|}{ Colilert } & \multirow{2}{*}{$\begin{array}{c}\text { Cloro } \\
\text { Residual } \\
\text { mgll }\end{array}$} & \multirow[t]{2}{*}{ Cor } & \multirow[t]{2}{*}{$\mathrm{PH}$} & \multirow[t]{2}{*}{ Turbidez } \\
\hline & & & \multirow{2}{*}{$\frac{\text { C. Total }}{\text { A }}$} & \multirow{2}{*}{$\frac{\text { E. Cole }}{\text { A }}$} & & & & \\
\hline 01 & \multicolumn{2}{|c|}{$\begin{array}{l}\text { Agua coletada no fim de rede- } \\
\text { Chafariz (em frente ao Cemitério) }\end{array}$} & & & 0,0 & 15,0 & 6,0 & 5,32 \\
\hline 02 & \multicolumn{2}{|c|}{$\begin{array}{l}\text { Agua coletada no fim de rede - } \\
\text { SAMAE }\end{array}$} & A & A & 0,0 & 25,0 & 6,1 & 5,36 \\
\hline \multicolumn{9}{|c|}{ CARACTERISTICAS FISICAS E ORGANOLÉPTICAS } \\
\hline \multicolumn{2}{|r|}{ PARĀMETROS } & \multicolumn{7}{|c|}{ PONTOS DE COLETAS } \\
\hline \multicolumn{2}{|c|}{$\begin{array}{l}\text { Limites Máximos } \\
\text { CONAMA } n^{\circ} 357 / 2005\end{array}$} & \multicolumn{3}{|c|}{$\begin{array}{c}\text { PONTO } \\
1\end{array}$} & \multicolumn{4}{|c|}{$\begin{array}{l}\text { PONTO } \\
2\end{array}$} \\
\hline \multicolumn{2}{|c|}{ Parâmetro } & Resultado & V.M.P & Unid. & Resultado & \multicolumn{2}{|r|}{ V.M.P } & Unid. \\
\hline \multicolumn{2}{|c|}{ Cor Aparente } & 15,0 & $\begin{array}{l}5 \text { RD P/ } 15 \\
\text { PRD }\end{array}$ & $\mathrm{UH}$ & 25,0 & & $\begin{array}{l}5 \text { RD P/ } 15 \\
\text { PRD }\end{array}$ & $\mathrm{UH}$ \\
\hline $\mathrm{PH}$ & & 6,0 & 6,0 a 9,5 & $\cdot$ & 6,1 & & 6,0 a 9,5 & $=$ \\
\hline Tubid & & 5,32 & $\begin{array}{l}1 \mathrm{RD} P / 5 \\
\text { PRD }\end{array}$ & UT & 5,36 & & $\begin{array}{l}1 \text { RD P/ } 5 \\
\text { PRD }\end{array}$ & UT \\
\hline Sabor & & $\cdot$ & $\begin{array}{c}\text { NAO } \\
\text { OBJETAV } \\
\text { EL }\end{array}$ & - & $=$ & & $\begin{array}{c}\text { NAO } \\
\text { BJETAVEL }\end{array}$ & . \\
\hline Odor & & - & $\begin{array}{c}\text { NĀO } \\
\text { OBJETAV } \\
\text { EL }\end{array}$ & - & - & & $\begin{array}{c}\text { NÁOO } \\
\text { BJETAVEL }\end{array}$ & - \\
\hline Cond & utância & - & $\cdot$ & $\begin{array}{l}\mathrm{Cm} P / \\
\text { UNHO }\end{array}$ & - & & $=$ & $\begin{array}{l}\mathrm{Cm} P / \\
\text { UNHO }\end{array}$ \\
\hline & & CAR & TTERISTICA & 5 QUIMICA & $\mathrm{S}(\mathrm{mg} / \mathrm{l})$ & & & \\
\hline & Parâmetro & Resultado & V.M.P & Unid. & Resultado & & V.M.P & Unid. \\
\hline Alcali & nidade $\mathrm{OH}$ & 0,0 & $=$ & $\mathrm{CaCo3}$ & 0,0 & &. & $\mathrm{CaCo} 3$ \\
\hline Alcali & nidade $\mathrm{CO} 3$ & 0,0 & . & $\mathrm{CaCo} 3$ & 0,0 & & . & $\mathrm{CaCo} 3$ \\
\hline Alcali & nidade $\mathrm{HCO} 3$ & 24,0 & - & $\mathrm{CaCo} 3$ & 26,0 & & - & $\mathrm{CaCo} 3$ \\
\hline $\mathrm{CO} 2$ & & 48,0 & - & $\mathrm{Co} 2$ & 42,0 & & - & $\mathrm{Co} 2$ \\
\hline Clore & & 32,0 & 250 & $\mathrm{Cl}$ & 33,0 & & 250 & $\mathrm{Cl}$ \\
\hline Durez & Total & 28,0 & 500 & $\mathrm{CaCo} 3$ & 20,0 & & 500 & $\mathrm{CaCO}_{3}$ \\
\hline Sulfat & & NR & 250 & $\mathrm{SO} 4$ & NR & & 250 & 504 \\
\hline Amōn & & NR & 1,5 & $\mathrm{NH} 3$ & NR & & 1,5 & $\mathrm{NH} 3$ \\
\hline Nitrat: & & NR & 10 & $N$ & NR & & 10 & $\mathrm{~N}$ \\
\hline Nitrito & & NR & 1,0 & $\mathrm{~N}$ & NR & & 1,0 & $\mathrm{~N}$ \\
\hline Ferro & Total & 0,26 & 0,3 & $\mathrm{Fe}$ & 0,31 & & 0,3 & $\mathrm{Fe}$ \\
\hline Mang & anês & NR & 0,1 & $\mathrm{Mn}$ & NR & & 0,1 & $\mathrm{Mn}$ \\
\hline Zinco & & NR & 5,0 & $\mathrm{Zn}$ & NR & & 5,0 & $\mathrm{Zn}$ \\
\hline Alumi & & NR & 0,2 & Al & NR & & 0,2 & Al \\
\hline Cobre & & NR & 2,0 & $\mathrm{Cu}$ & NR & & 2,0 & $\mathrm{Cu}$ \\
\hline Potás & & NR & - & $\mathrm{K}_{+}$ & NR & & $\cdot$ & K. \\
\hline Fluore & tos & 0,1 & 1,5 & $\mathrm{~F}$ & 0,11 & & 1,5 & $\mathrm{~F}$ \\
\hline Sólide & 1s Totais & NR & 1.000 & - & NR & & 1.000 & - \\
\hline Cloro & Residual & 0,0 & 5 & $\mathrm{Cl} 2$ & 0,0 & & 5 & $\mathrm{Cl} 2$ \\
\hline Oxige & nio Dissolvido & NR & - & $\mathrm{O} 2$ & NR & & . & $\mathrm{O} 2$ \\
\hline & & & LEC & $\overline{D A}$ & & & & \\
\hline C. & Coliforme & otal & & ND & Não Detectad & & & \\
\hline E. & Escherich & Cole & & NR & Não Realizado & & & \\
\hline & Ausente & $100 \mathrm{ml}$ da an & stra & ND & Não Determin & ado & & \\
\hline & Presente & $\mathrm{n} 100 \mathrm{ml}$ da a & ostra & RD & Reservatorio & de Distr & tribuiçaెo & \\
\hline & Ponta de & ede de Distrib & & $\mathrm{uH}$ & Unidade de $\mathrm{H}$ & azen & & \\
\hline & Unidade & Turbidez & & VMP & Valor Máximo & Permis & issivel & \\
\hline
\end{tabular}

Fonte: Análise laboratorial, 2016

Geografia, Ensino \& Pesquisa, Vol. 21 (2017), n.2, p. 174-187

ISSN: 2236-4994 DOI: $10.5902 / 2236499424277$ 
As pessoas que precisam recorrer ao chafariz podem contrair algum tipo de doença, pois água além de não ser tratada ainda pode estar contaminado, por necrochorume. Se houver canos danificados e a agua entrar em contato com o mesmo, os moradores informaram que a agua fornecida pelo SAMAE foi implantada para não ser paga, pois se trata de uma localidade, onde a população é desfavorecida. Atualmente os usuários pagam uma taxa de $\mathrm{R} \$ 17,00$. O gestor na época construiu a barragem nova, como é conhecida, para o fornecimento de água. Nas residências não possui hidrômetro; por este motivo, quando os funcionários do SAMAE fazem o desligamento diretamente nas casas, os moradores religam e continua utilizando a água (gráfico 1).

O gráfico 1 apresentado mostra que menos da metade das pessoas entrevistadas consomem água do referido chafariz. Todavia esse resultado nos revelam que $25 \%$ ainda correm riscos por consumir uma água que não é potável, e se houver algum vazamento no sistema de abastecimento a mesma fica propícia a contaminar-se por necrochorume e a população adquirir algum tipo de doença viral ou bacteriana oriunda do mesmo (gráfico 2).

\section{Consumo da água do}



-

Gráfico 1 - Consumo da água do Chafariz

Fonte: Arquivo pessoal dos autores, 2016

A população do entorno do cemitério sente ou já sentiu um odor vindo do cemitério gráfico 2. Algumas afirmam que o mal cheiro está menos frequente devido à profundidade das covas. "Segundo dona Rosana de 41 anos, residente na rua Miguel Alves, os coveiros estão tendo mais cuidado e cavando as covas mais profunda e por isso o mal cheiro diminuiu, é mais frequente a noite". O vazamento no sistema de esgoto também aumento a probidade do mal cheiro no cemitério, pois o corpo demora a se decompor.

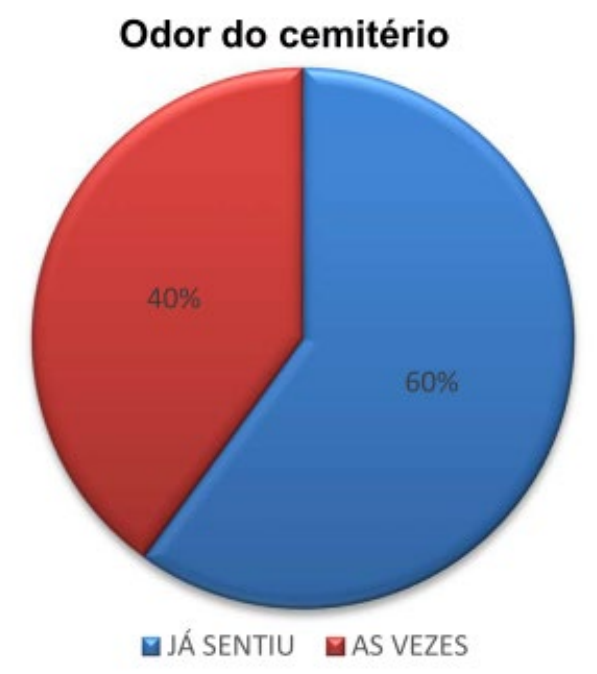

Gráfico 2 - odor oriundo do cemitério

Fonte: Arquivo pessoal dos autores, 2016

Recentemente houve uma ampliação do cemitério, mas por falta de planejamento este novo local já se encontra lotado de problemas que vão de encontro com o que rege a legislação. Os principais problemas que encontramos foram: alagamento em grande parte do cemitério, trazendo um grande risco da terra ceder e acelerar o processo de decomposição dos cadáveres, e consequentemente proporcionando o escoamento do necrochorume no solo e possibilitando a contaminação dos lençóis freáticos, esgoto a céu aberto e bastante lixo acumulado, deixando a população a mercê de possíveis doenças (figura 10), e o pior, o poder público municipal permitiu que se construíssem casas ao seu redor do cemitério que é proibido pelo CONAMA.

Devido à falta de recolhimento do lixo pelo poder público, os moradores fazem com quer os resíduos dividam espaços com os túmulos, podendo ocasionar mais um grande impacto, pois o chorume gerado pelos resíduos pode penetrar nas catacumbas e descompactar o solo, permitindo também a entrada de ar e acelerando assim o processo de decomposição dos cadáveres.

\subsection{Legislação Pertinente para a Implantação de Ce- mitérios}

Os cemitérios necessitam estar de acordo com algumas leis vigentes. O Conama é um órgão com lei de esfera federal que padroniza os mesmos, regularizando os tipos de covas e sua profundidade, a área na qual o cemitério pode ser implantado, as proximidades exata com lençóis freáticos, o sistema de drenagem do necrochorume, etc. O Instituto de 
Meio Ambiente-IMA é o órgão responsável, pelo licenciamento ambiental de empreendimentos que possam alterar o meio ambiente. Ele também age como fiscalizador de danos gerados ao mesmo. Para concessão do empreendimento, o IMA faz uma avaliação do impacto ambiental/AIA.

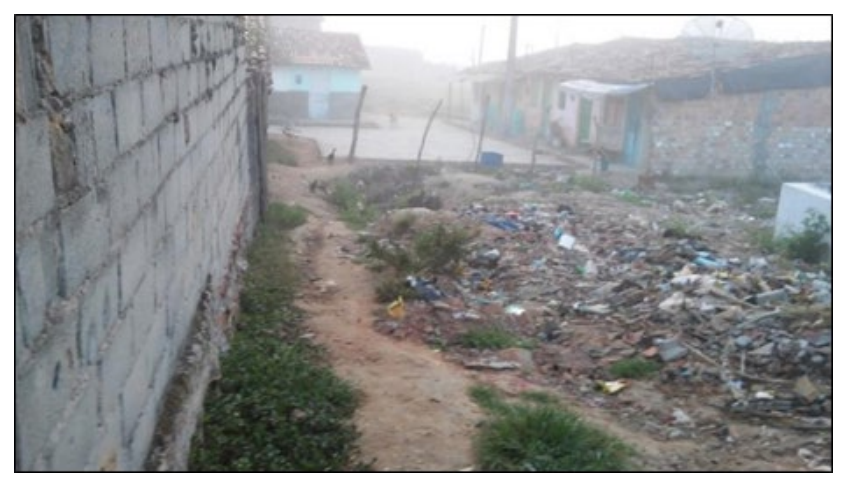

Figura 10 - acúmulo de lixo no cemitério

Fonte: Arquivo pessoal dos autores LATITUDE: $8^{\circ}$ 58' 32, 24" S LONGITUDE: $35^{\circ} 55^{\prime} 51,07^{\prime \prime} \mathrm{W}$

A implantação do cemitério deve ser estudada de forma criteriosa, pois o mesmo traz várias consequências tanto ambiental, social e sanitária. Desta forma, deve-se tomar todas as medidas de proteção ao meio ambiente. A contaminação por necrochorume é um fator que deve ser considerado, até mesmo o local inadequado dos túmulos pode propiciar o extravasamento do necrochorume e contaminando o solo e as águas subterrâneas.

No estado de Alagoas existe uma lei para os tipos de empreendimento sujeito ao licenciamento ambiental, lei $\mathrm{n}^{\circ}$ 7.625 de 22 de maio de 2014 e Lei no 6.787, de 22 de dezembro de 2006, que regulariza os estabelecimentos comerciais e de serviços, os cemitérios, dentre os outros. Nesta lei vigente são estipuladas medidas e penalidades rigorosas para seu descumprimento.

O Cemitério Campo Santo José Augusto não se enquadra nas leis vigentes em nenhuma das esferas, como a 335/336 de 2003/2006 do Conselho Nacional do Meio Ambiente, que determina "o estudo do solo, o planejamento de cemitérios". Ficou constatado que o cemitério de Ibateguara não possui licenciamento, não toma medidas de proteção ao meio ambiente e a profundidade das covas não atende ao CONAMA. O mesmo não possui uma lei orgânica para amenizar possíveis impactos; não há sequer o serviço básico de manutenção. Além disso, a encanação de um sistema de água está localizada em frente ao cemitério; o mesmo serve de abastecimento para algumas residências.

Para agravar ainda mais a situação, os funcionários não estão protegidos de possíveis acidentes, de forma que não usam os Equipamentos de Proteção individual - EPIs, principalmente os coveiros, que devem usá-los por estarem expostos a contraírem doenças por fungos e bactérias, devido à decomposição do necrochorume. Segundo o ministério do trabalho e emprego os EPIs, são os mesmos utilizados na construção civil: botas, luvas grossas, óculos de segurança e capacete. No município de Ibateguara, além do risco da contaminação por necrochorume, o cemitério encontra-se sem nenhuma infraestrutura com esgoto a céu aberto, atraindo vários tipos de vetores causadores de doenças que podem afetar tanto os coveiros quanto à população.

\section{CONSIDERAÇÕES FINAIS}

Diante dos fatos apresentados, e a respeito do estudo realizado, verificamos que os impactos ambientais causados por cemitérios estão sujeitos a acontecerem em todo e qualquer cemitério, desde que não haja cuidados na implantação e manutenção do mesmo; tornando-se assim uma questão de saúde pública. Analisando as legislações vigentes no país encontramos diversas irregularidades no cemitério da cidade de Ibateguara no estado de Alagoas; fatos que vão de encontro com o que é exigido por lei, de forma que ferem a legislação e possibilitando diversos impactos ambientais ao solo e aos lenções freáticos. A princípio, o cemitério está localizado dentro da cidade, o que não permitido pelo CONAMA.

Verificou-se que, nos estudos realizados no cemitério de Ibateguara, o mesmo encontra-se irregular. Atribuímos essa culpa à falta de interesse dos órgãos públicos e a escassez de fiscalização dos departamentos competentes. Por esse motivo, fica claro que o cemitério de Ibateguara não possui planejamento, e nem um tipo de documentação que prove sua regularização, levando a ser um cemitério fora dos padrões exigidos por lei.

A partir do trabalho em foco, foram constatadas várias irregularidades no Cemitério Campo Santo José Augusto da cidade de Ibateguara, e para tentar contornar esta situação recomendamos: a implantação de um planejamento para o Cemitério, a manutenção constante da área que se encontra no Cemitério Campo Santo José Augusto da cidade de Ibateguara, a retirada imediata da encanação da água que está dividindo solo com Cemitério, pelo fato da mesma abastecer boa parte da população da cidade citada, um tratamento rigoroso das águas do Chafariz, localizado em frente ao Campo Santo José Augusto da cidade de Ibateguara e também na água fornecida pela SAMAE, já que esta abastece para o consumo.

É importante observar que, atuação constante pelo poder público para zelar pela área é importante, bem como uma fiscalização periódica dos órgãos competentes e pôr fim a obrigatoriedade dos EPIS e a implantação de um novo cemitério, conforme o que rege a legislação. 


\section{REFERÊNCIAS}

ALAGOAS. Companhia de Saneamento de Alagoas-CASAL. Disponível em: http://casal.al.gov.br/. Acesso em: 23/06/2016.

ALAGOAS. Enciclopedia dos Municípios de Alagoas. Disponível em: www.youblisher.com/p/525211-Enciclopedia-dos-Municipios-de-Alagoas/. Acesso em: 10 de Maio 2016 as $18 \mathrm{~h} 00 \mathrm{~min}$.

ALAGOAS. INSTITUTO DO MEIO AMBIENTE DE ALAGOAS-IMA. Licenciamento ambiental. Lei 7.625/2014. Disponível em: http://ima.al.gov.br/. Acesso em: 23/06/2016.

BRASIL. AGÊNCIA NACIONAL DE ÁGUA-ANA. Cadastro Nacional de Usuários de Recursos Hídricos-CNARH. Brasília, DF. 2008. P. 85. Disponível em: http://cnarh.ana.gov.br/sistemacnarh.aspx. Acesso em: 23/06/2016.

BARROS, Y. J.; MELO, V. F.; et al. Teores de metais pesados e caracterização mineralógica de solos do cemitério municipal de Santa Cândida, Curitiba (PR). Revista Brasileira de Ciência do Solo. Vol. 32, n. 4, p. 1763-1773, 2008.

BARROS, A. J. S.; LEHFELD, N. A. S. Fundamentos de Metodologia Científica. 3.ed. São Paulo: Prentice Hall, 2007.

BRASIL. MINISTÉRIO DO MEIO AMBIENTE-MMA. Resolução CONAMA No 237-1997. Dispõe sobre o licenciamento ambiental. Disponível em: www.mma. gov.br/port/conama/res/res97/res23797.html. Acesso em: 23/07/2016

BRASIL. MINISTÉRIO DO MEIO AMBIENTE-MMA. Resolução Conama no 001- 1986. Dispõe sobre avaliação de impacto ambiental. Disponível em:http:// www.mma.gov.br/port/conama/res/res86/res0186.html. Acesso em: 23/06/2016.

BRASIL. MINISTÉRIO DO MEIO AMBIENTE-MMA. Resolução CONAMA $\mathbf{n}^{\circ}$ 368-2006. Dispõe sobre o licenciamento ambiental de cemitérios. Disponível em: http://www.mma.gov.br/port/conama/legiabre. cfm?codlegi=488. Acesso em: 27/08/2016.
BRASIL. MINISTÉRIO DO MEIO AMBIENTEMMA - Resolução CONAMA 335/2003. Dispõe sobre o licenciamento ambiental de cemitérios. Disponível em: http://www.mma.gov.br/port/conama/legislacao/CONAMA_RES_CONS_2003_335.pdf1. Acesso em: 16 de fevereiro as $17 \mathrm{~h} 38 \mathrm{~min}$

CEMITÉRIO VERTICAL. Disponível em: http://memorialsantos.com.br/. Acesso em 18 de agosto de 2015.

CAMPOS, A. P. S. Avaliação do potencial de Poluição no Solo e nas Águas Subterrâneas decorrente da atividade cemiterial. 2007. 141p. Dissertação (mestrado em Saúde Pública) - Universidade de São Paulo, São Paulo.

CARNEIRO, G. B.; FRANCISCO, M. R.; PEREIRA JUNIOR, V. A. Impactos ambientais causados por cemitérios. 2010. 135p. TCC (trabalho de Conclusão de Curso em Engenharia Ambiental)-Faculdade de Caldas novas, 2010, Goiás.

CORRÊA, R. L. O Espaço Urbano. São Paulo: Àtica, 1989.

INSTITUTO BRASILEIRO DE GEOGRAFIA E ESTATÍSTICA - IBGE. Mapas. Rio de Janeiro: IBGE, 2016. Disponível em: http://cidades.ibge.gov.br/xtras/perfil. php?codmun=270300. Acesso em: 01 de Abril 2016.

KEMERICH, P. D. C.; BIANCHINI, D. C.; FANK, J. C.; BORBA, W. F.; WEBER, D. P.; UCKER, F. E. A questão ambiental envolvendo os cemitérios. REMOA. V. 13, n. s, p. 3777 - 3785, (Edição especial), 2014.

LEITE, E. B. Análise Físico-química e Bacteriológica da água de poços localizados próximo ao cemitério da comunidade de Santana, Ilha de Maré, Salvador- BA. Candombá - Revista Virtual, v. 5, n. 2, p. 132-148, 2009.

MATOS, B. A. Avaliação da Ocorrência e do Transporte de Microrganismos no Aquífero Freático do Cemitério de Vila Nova Cachoeirinha, Município de São Paulo. São Paulo. 2001. 172 p. Tese (Doutorado em Geociências) - Universidade de São Paulo, São Paulo.

MUMFORD, L. A cidade na história: suas origens, transformações e perspectivas. Trad.: Neil R. da Silva. 4 ed. São Paulo: Martins Fontes, 1998 
MUNICÍPIO. Serviço Autônomo Municipal de Agua e Esgoto-SAMAE. Disponível em: http://www.ibateguara. al.gov.br/?pg=noticias-destaques. Acesso em: 14 de Março 2016, as $11 \mathrm{~h} 41 \mathrm{~min}$.

MUNICÍPIO. Prefeitura Municpal de Ibategura. Disponível em: http:/ / www.ibateguara.al.gov.br/?pg=noticias-destaques. Acesso em: 14 de Março 2016, as 11h41min.

NOGUEIRA, C. O. G.; JÚNIOR, J. E. C.; COIMBRA, L. A. B. Cemitérios e seus Impactos Socioambientais no Brasil. IX Fórum ambiental da alta paulista, v.9, n.11, p.331-334, 2013.

\section{ORGANIZAÇ̃̃O MUNDIAL DE SAÚDE-OMS. Obe-} sity: preventing and managing the global epidemic Report of a WHO consultation, Geneva: WHO, 1997.

PESSOA DE MELO, F.; MELO E SOUZA, R. Modelagem Geofísica: Subsídios para Gestão Ambiental em Garanhuns-PE. In: MELO E SOUZA, R.; SANTOS, S. S. C.; SANTOS, E. A. (orgs.) Vivências e práticas socioambientais: metodologias aplicadas em comunidades São Cristóvão, SE. GEOPLAN/CNPQ/ UFS, 2015. 200p.

PESSOA DE MELO, F.; MELO E SOUZA, R. Reterritorialização do Espaço Agrário Pernambucano, a Partir de Políticas Públicas Governamentais em Garanhuns-PE: Erradicação do Café e Implantação da Bacia Leiteira. Boletim DATALUTA. NERA - Núcleo de Estudos, Pesquisas e Projetos de Reforma Agrária. Jun. 2015.

PESSOA DE MELO, F; MELO E SOUZA, R.; SANCHES ROSS, J. L. Modelagem de Geoformas para Mitigação do Risco Geoambiental em Garanhuns-PE. Acta Geográfica, v.10, n.22, p. 87-105, 2016.

SEVERINO, A. J. Metodologia do trabalho científico. 23. ed. Revisada. e atualizada. São Paulo: Cortez, 2007.

\section{Correspondência dos autores:}

Célio Martins da Rocha

e-mail: martinsagfm@hotmail.com

Claudionor de Oliveira Silva

e-mail: geografia.gestao@hotmail.com

Elayne Cristina Pereira dos Santos e-mail: layne-cristina@hotmail.com

Artigo recebido em: 04/10/2016

Revisado pelo autor em: 08/04/2017

Aceito para publicação em: 10/05/2017 